\title{
Widespread and Indiscriminate Nanosilver Use: Genuine Potential for Microbial Resistance
}

\author{
${ }^{*}$ Cindy Gunawan ${ }^{1,2}$, Christopher P. Marquis ${ }^{3}$, Rose Amal $^{2}$, Georgios A. Sotiriou ${ }^{4}$, Scott A. Rice ${ }^{5,6}$ \\ \& Elizabeth J. Harry ${ }^{1}$
}

\begin{abstract}
In the era of increasing antibiotic resistance, the use of alternative antimicrobials such as silver has become more widespread. Superior antimicrobial activity has been provided through creation of silver nanoparticles or nanosilver (NAg) that impart cytotoxic actions distinct from bulk silver. In the wake of the recent discoveries of bacterial resistance to NAg and its rising incorporation in medical and consumer goods such as wound dressings and dietary supplements, we argue an urgent need to monitor the prevalence and spread of NAg microbial resistance. This Perspective describes how the use of NAg in commercially available products facilitates prolonged microorganism exposure to bioavailable silver, which underpins the development of resistance. Furthermore, we advocate for a judicial approach towards NAg use in order to preserve its efficacy and avoid environmental disruption.
\end{abstract}

${ }^{1}$ The ithree institute, University of Technology Sydney, Sydney, Australia. ${ }^{2}$ School of Chemical Engineering and ${ }^{3}$ School of Biotechnology and Biomolecular Sciences, The University of New South Wales, Sydney, Australia. ${ }^{4}$ Department of Microbiology, Tumor and Cell Biology, Karolinska Institutet, Stockholm, Sweden. ${ }^{5}$ Singapore Centre on Environmental Life Sciences Engineering and ${ }^{6}$ School of Biological Sciences, Nanyang Technological University, Singapore. 


\section{Silver has long been used as an antimicrobial but its effectiveness is now under threat}

Humans, since their first existence, have had to co-exist with microorganisms and adapt to their dominating presence ${ }^{1}$. Microorganisms reside in our bodies and we are increasingly aware of the extent to which communities of microorganisms shape our physical and mental health and of the value in keeping these communities in balance ${ }^{1}$. To manage those among the microorganisms that are or become pathogenic, we use antimicrobials either prophylactically, to prevent infection, or as treatment for established infection. Antimicrobials include more than antibiotics; before and since the discovery of antibiotics other antimicrobials have been used, including disinfectants, and notably, silver. Silver has broad-spectrum antimicrobial activity ${ }^{2}$ and yet seemingly low toxicity for humans ${ }^{3}$. As resistance to antibiotics rises exponentially and resistance to new-generation biocides such as triclosan appears ${ }^{4,5}$, the ability to rely on silver and other less conventional antimicrobial treatments assumes even greater importance and this has led to growing momentum in the design, engineering and applications of nanosilver $(\mathrm{NAg})^{6-8}$. The appeal of NAg is that its distinct physical, chemical and biological properties deriving from its smaller size (metallic or oxide silver particulates with 1-100 $\mathrm{nm}$ dimensions of the particles) afford its greater efficacy as an antimicrobial at lower concentrations, relative to larger micronsized bulk silver.

The reliability of silver as an antimicrobial is, however, under threat. In 2014, the European Commission's Scientific Committee on Emerging and Newly Identified Health Risks (SCENIHR) ${ }^{9}$, recognised a 'serious knowledge gap' concerning the use of silver nanoparticles and the potential consequent development of resistance mechanisms to them. This Perspective analyses this potential consequence and argues that a real threat exists that resistance to antimicrobial NAg will develop and propagate throughout communities of microorganisms, including those that reside in our bodies. Fuelling this threat is the rapid, widespread, and indiscriminate expansion of NAg application. NAg is now used as a core or co-antimicrobial ingredient in consumer products across numerous application categories, with major usage in health and fitness (personal care, medical care, as dietary supplements), in clothing and other textiles, as well as in home and garden (filters, household appliances and cleaning) and even baby 
products $^{10,11}$. Here, we examine the NAg applications in medical care and dietary supplements for their potential to facilitate prolonged microorganism exposure to bioavailable silver, a key factor in development of resistance in microbial communities. These NAg applications involve direct human contact, facilitating the potential release, absorption, distribution and in turn, accumulation of bioavailable silver in microorganism-inhabited organs and tissues.

\section{The terminology of bioavailable silver from nanosilver}

The emphasis in this Perspective will be on 'bioavailable silver' - a term we use in relation to NAg that refers to both Ag particulates and soluble Ag that leach from such particulates; the emphasis here is on bioavailable silver rather than on whether the product on the shelf contains silver or NAg (Box 1 and Figure 1). This emphasis is because not all forms of silver exert cytotoxicity against microorganisms. Silver can be present in a product in one form (metallic silver $(\operatorname{Ag}(0))$ particulates, silver oxide particulates, or cationic silver in various compounds) but can transform through aggregation, agglomeration, dissolution and chemical speciation into alternative forms when the product is in use $\mathrm{e}^{12}$. That is, when the silver makes contact with a new environment, such as those occurring when wound dressings are applied and contact is made with the body fluids. Cytotoxic action against microorganisms depends on the bioavailability of the silver, and it is increasingly realised that silver nanoparticles, their bulk silver $(>100 \mathrm{~nm})$ counterparts and cationic silver have distinct cytotoxic actions on microorganisms ${ }^{13-16}$. NAg exhibits superior size- and shape- dependent antimicrobial activity through the action of undissolved Ag particulates, in addition to that from the 'nano-sized' enhanced leaching of soluble silver ${ }^{13,14,17-19}$. Thus, our emphasis is guided by the fact that what is important for the development of resistance to silver is the prolonged exposure of a microorganism to forms of silver that are able to exert biological action on the cell, rather than the form of silver in the product at the point of sale. Attention is drawn particularly to NAg because of its exponential applications, for which antimicrobial action is included for a commercial purpose apart from medical applications. 


\section{Microorganisms can develop resistance to nanosilver}

Before the dramatic increase in application of silver nanoparticles as an antimicrobial, ionic silver has had a long history of use as a disinfectant. Many reports frequently use the term 'silver' when referring to silver ions. Decades-old discoveries provide evidence on the potential of microorganisms to develop resistance to chemical species of silver that are cytotoxic, so that the microorganisms continue to grow even in the presence of silver. One of the earliest reports of antimicrobial resistance to silver ions was by Jelenko et al.in 1969. The study isolated resistant Escherichia coli from a clinical case of prolonged silver nitrate-treated burns (detected at day 47, following treatment with $0.5 \%$ silver nitrate at day 1 and day 36 post-burn $)^{23}$. This was followed by the discovery of a silver-resistant Salmonella typhimurium strain in the 1970s, also isolated from clinical cases of silver nitrate-treated burns (detected as early as day 8 , following treatment with $0.5 \%$ silver nitrate $)^{24}$. The isolated strain was later characterised as having nine resistance determinants, known as the sil genes ${ }^{25}$. Examples of bacteria adapting to conditions of long exposure to silver are also found outside the clinic, in specific environmental settings 'where toxicity might select for resistance' (a quote from A. Gupta and S. Silver, 1998), including the soil of a silver mine and photographic laboratory effluent ${ }^{6,26}$.

Given the difference in cytotoxic action against microorganisms by different silver chemical species, it may not necessarily follow from the earlier studies that microorganisms exposed to silver nanoparticles will adapt and develop resistance traits to the nanoparticle exposure. It is thus an important question to ask: can microorganisms develop resistance to NAg?

The answer is yes, they can. In 2013, we reported the natural ability of the ubiquitously occurring Bacillus sp. bacteria genus to adapt to NAg in the forms of both high tolerance to NAg and enhanced proliferation $^{27}$. The ability of Bacillus sp. to grow when exposed to NAg levels higher than the microbial toxicity threshold is a result of prolonged prior exposure to NAg. Although the mechanisms by which microorganisms develop resistance effects to NAg are yet to be understood, they may involve defence to oxidative damage invoked by exposure to bioavailable silver ${ }^{27}$. Notably, lethal levels of NAg-stimulated cellular oxidative stress were not required for resistance to develop in Bacillus sp.; the resistance effects 
also developed upon prolonged exposure to benign levels of NAg-stimulated cellular oxidative stress. The observed adaption was maintained in the population so that the enhanced proliferation continued even in the absence of NAg exposure. The enhanced proliferation of the Bacillus sp. enabled them to dominate the model microbiota that was the subject of the study (detection of resistant Bacillus sp. as early as day 3 using $3 \mathrm{mg} \mathrm{Ag} / \mathrm{L})^{27}$. Bacillus sp. were not the target of the application of NAg $-E$. coli was, but were rather an environmentally-occurring airborne microorganism introduced at low-levels to contribute to a test microbiota. Similarly, another resistance study to NAg by Khan et al. detected resistant Bacillus sp. from sewage, this time in only $24 \mathrm{~h}$ using the extremely high $100 \mathrm{mg} \mathrm{Ag} / \mathrm{L}^{28}$. In 2015, Graves et al. observed NAg tolerance in E. coli of clinical origin, again manifesting upon prolonged exposure (detection between 23 to 29 days of treatment with 50 to $125 \mu \mathrm{g} / \mathrm{L} \mathrm{NAg})^{29}$.

Published studies describing resistance to various forms of silver raise the cornerstone question for this Perspective: could the increased use of NAg in a wide range of products facilitate prolonged microorganism exposure to bioavailable silver and therefore the development of resistance in real-world settings? And more importantly, how? To address these questions, we investigated more than 140 commercially-available medical care and dietary supplement products with proven NAg contents or proven presence of $\mathrm{Ag}$ for the claimed NAg or Ag ingredients, with reference to published scholarly articles as well as manufacturer-funded in vitro and in vivo studies. In our analysis, we identified the following: (1) the potential release of Ag ions upon contact with body fluids, (2) the subsequent routes of absorption, distribution and accumulation of Ag along with its corresponding chemical transformation and finally, (3) the potential exposure of microflora at sites with prolonged accumulation of bioavailable Ag (see Supplementary Table S1, S2 and S3). Our investigation took into account the complexities of silver. Incorporation of non-nanoscale silver in the products, such as silver salts and micron-sized metallic silver, could in fact result in the formation and release of 'secondary' NAg particulates. Ionic silver is capable of undergoing chemical transformation to form nano-sized Ag particulates in biological environments $^{12,30,31}$, while metallic silver even as large pieces, has been shown to release NAg particulates under humidity-dependent conditions ${ }^{32}$. In summary, our investigation found that applications 
of NAg (or silver) in medical care or as dietary supplements could facilitate prolonged microorganism exposure to bioavailable silver in the human body and therefore, the potential for resistance development. Likely sites for exposure within the human body that we identified include wound bed, oral cavity, gastrointestinal and urinary tracts, all densely-populated microbial habitats with persistent presence of bioavailable silver (Figure 2), as described in more detail below.

\section{Increasing use of nanosilver products can facilitate prolonged microorganism exposure to bioavailable silver}

The commercialisation of silver-containing medical products has seen incorporation of many forms of silver ranging from bound cationic $\mathrm{Ag}(\mathrm{I})$, such as silver sulphadiazine and silver sulfate, to the more current and technologically advanced applications of nanocrystalline metallic and oxide silver (Table S1). For wound dressings, these various forms of silver are coated on or impregnated in alginates, polymerbased mesh, fibres and foams as well as hydrogels, hydrofibres and hydrocolloids. Incorporation of silver in catheters involves coating of latex or silicone base materials with the silver in alloyed or hydrogel forms. The desired antimicrobial activity observed for these silver-containing products originates from their contact with relevant body fluids - wound exudates for wound dressings, bloodstream, urine or respiratory tract fluid for central venous, foley or tracheal catheters respectively, sustainably releasing Ag ions over a prolonged period ${ }^{33,34}$. Typically 3 to 7 days and for some products, up to 21 days of $\mathrm{Ag}$ ion release, have been observed or claimed for wound dressings, while longer release periods of 4 weeks or more are generally the case for catheters. An often overlooked, yet crucial, fact is that the bioavailability and therefore the cytotoxicity of the released $\mathrm{Ag}$ ions is affected by their further interactions with halide anions $\left(\mathrm{Cl}^{-}, \mathrm{Br}^{-}, \mathrm{I}^{-}\right)$as well as biomolecules and proteins as silver-precipitating and silver-complexing agents in the body fluids ${ }^{30,33,35}$. For example, the soluble $\mathrm{Ag}(\mathrm{I})$-halide anionic complexes (such as $\mathrm{AgCl}_{2}^{-}$, $\mathrm{AgCl}_{3}{ }^{2-}$ ) and organo $\mathrm{Ag}$-peptide complexes can interact with bacteria and cause cytotoxicity ${ }^{30,36-38}$. If present in microbial habitats, the prolonged generation of these bioavailable silver species from the interaction of silver-containing medical products and body fluids suggests the possibility of resistance development. 
To clearly demonstrate this, let us take a closer look at the fates, the series of chemical transformation and the potential of prolonged microorganism exposure to the bioavailable silver derived from wound dressings (see Table S1 for more details). Upon their release, Ag ions interact with the typically abundant presence of chloride and serum proteins in the wound environment ${ }^{39}$. Such interactions will potentially result in the formation of bioavailable Ag species - the soluble $\mathrm{Ag}(\mathrm{I})$-chloride anionic complexes (e.g. $\left.\mathrm{AgCl}_{2}{ }^{-}, \mathrm{AgCl}_{3}{ }^{2}\right)^{33,36,37}$, organo $\mathrm{Ag}$ complexes ${ }^{33,38}$, with a maximum of $1 \mu \mathrm{g} / \mathrm{mL}$ silver expected to remain as free ions ${ }^{40}$. Note that there could also be presence of the biologically inert $\mathrm{AgCl}$ precipitate ${ }^{33,35,36}$ and in the case of NAg dressings, the likely presence of Ag particulates on wound beds will contribute to additional cytotoxic effects ${ }^{13,14}$ (also see Table S3 for forms of silver species in wounds and their bioavailability). Localised exposure of wound microflora to such continual presence of bioavailable silver could facilitate resistance development, in particular with the repeated wound dressing applications on the infection-prone burns and chronic wounds. Apart from contamination by members of the gastrointestinal (gut), the oral cavity and the genitourinary microflora ${ }^{41}$, wounds are also a potential breeding ground for members of the surrounding skin microflora and even the exogenous air-borne microorganisms ${ }^{41,42}$, of which the latter include Bacillus sp. ${ }^{43,44}$. With a bacterial burden of at least $10^{5} \mathrm{CFU}$ (colony forming units) per gram tissue typically observed in infected wounds ${ }^{41,45}$, there have indeed been incidences of prevalence and invasive infections of silver-resistant bacteria arising from the wound care applications of silver $^{46-48}$. This is not contradictory to the in vitro observation of aggressive proliferation of resistant bacteria (exogenous Bacillus sp.) following prolonged exposure to $\mathrm{NAg}^{27}$. Further, bacteria containing sil genes with increased persistence to growth inhibition by silver have been detected in members of wound microflora $^{49}$; although we do not rule out the possibility that such prevalence may be partly attributed to the phenomena of microorganism-to-microorganism transfer of resistance determinants, as later discussed. In 2016, a spontaneous resistance phenomenon was observed in the wound pathogen Proteus mirabilis following one-off exposure to NAg wound dressings, presenting a firmer evidence on the potential implications of NAg wound care applications ${ }^{50}$. 
The fate of silver applied to the body through application of wound dressings is not limited to chemical transformations and accumulation in wounds. In cases of prolonged wound dressing application and/or treatment of large wounds, silver has been found to enter the bloodstream through systemic absorption (see Table S1) ${ }^{34}$. Here, the absorbed Ag species predominantly exist as organo species due to the high affinity of $\mathrm{Ag}$ ions for the thiol (-SH) groups of the amino acids cysteine and methionine present in serum albumins, metallothioneins and macroglobulins ${ }^{51-53}$ as well as in reduced glutathione (GSH), a small antioxidant peptide $\mathrm{s}^{30,54}$. Ag ions also have strong affinities for the amino acids histidine, arginine and lysine ${ }^{55-57}$, which are also thought to be the preferential binding sites of silver in peptides, proteins and biomolecules $^{12}$. Note that it remains unclear at this stage as to the exact routes of silver absorption into the bloodstream and the identities of the absorbable silver species, with several research inquiries leaning toward the systemic uptake of $\mathrm{Ag}$ ions $\mathrm{s}^{30,34}$ and $\mathrm{Ag}$ complexes with mobile proteins ${ }^{34}$. Detection of up to $230 \mu \mathrm{g} / \mathrm{L} \mathrm{Ag}$ in blood (normal Ag concentrations are less than $1 \mu \mathrm{g} / \mathrm{L}$ ) has been reported with up to 28 day applications of NAg-containing dressings on burns ${ }^{58}$. Importantly, Trop et al. detected a 140-fold silver level increase in urine at the end of a 7-day treatment course with NAg dressings on burns (relative to the normal concentration of $0.2 \mu \mathrm{g} \mathrm{Ag} / \mathrm{kg})^{59}$, and as also reported in other studies, persisted before gradually returning to normal levels following discontinuation of the NAg treatment ${ }^{59,60}$. Silver in urine and therefore in urinary tract, is thought to result from $\mathrm{Ag}$ ions and small-sized organo $\mathrm{Ag}$ species in the bloodstream passing through the kidney filtration system ${ }^{61}$. Such prolonged presence of bioavailable silver raises the possibility of development of resistant microorganisms (also see Table S3 for forms of silver species in urine and their bioavailability). Similar to wounds, the urinary tract is a microbial habitat. Apart from the known prevalence of fast-growing microorganisms, quite recent innovations in biomolecular techniques have allowed identification of slow-growing and delicate microorganisms dwelling in the urinary tract, which are otherwise uncultivable with traditional methods ${ }^{62}$. The potential for exposure of these unique microbial communities to bioavailable silver is even more likely with the use of NAg (or Ag)-containing urinary catheters with on-site prolonged release of $\mathrm{Ag}$ ions. 
Similarly concerning are the widely marketed NAg dietary supplements. More than simply marketing hype, studies have validated the claimed presence of NAg particulates in many oral supplements as well as in throat and nasal sprays ${ }^{63-65}$. These NAg (or Ag) applications are likely to facilitate direct accumulation of bioavailable silver in organs and tissues with resident commensal microflora. Without the need for systemic absorption into the bloodstream, deposition of bioavailable silver in the oral cavity and gastrointestinal tract is anticipated following oral intake and ingestion of silver ${ }^{51,66}$ or in the respiratory tract following inhalation of silver ${ }^{65,67}$. These densely-populated microbial habitats harbour widely diverse microbial communities - including Bacillus sp. as members ${ }^{1,68-71}$, that are potentially responsive to the prolonged presence of bioavailable silver to develop resistance effects (see Table S2 and S3 for more details on the fates, chemical transformation and the potential of prolonged microorganism exposure to bioavailable silver at these sites). Not surprisingly, there have been reports of members of gut microflora carrying functional sil genes, with proven resistance to silver ${ }^{35,48}$. Furthermore, systemic absorption of silver through the buccal (oral cavity) ${ }^{51}$, gastrointestinal ${ }^{30,51}$ and lung alveolar ${ }^{51}$ mucosa has been associated with detection of elevated and persistent silver levels in urine ${ }^{72-74}$ and therefore ultimately, the potential for prolonged exposure of urinary microflora to bioavailable silver. The resistance potential aside, the intended accumulation of bioavailable silver in the gut with $\mathrm{Ag}$ ingestion could eradicate beneficial resident microflora, leading to colonisation and overgrowth of pathogens in the gut $^{75}$. It has also been well established that changes in the dynamic and balance of gut microflora may lead to an array of undesirable host functions, including inflammation and disrupted energy balance ${ }^{1,76}$.

Development of resistance to bioavailable silver by microorganisms residing in an individual increases the vulnerability of that individual to infections arising, for example, from medical procedures relying on silver as an antimicrobial in situations whereby antibiotics are less effective (e.g. insertion of catheter). The resistant microorganisms may spread to other individuals and to the environment and simply increases the pool of resistance determinants. Silver resistance determinants have been increasingly detected in a wide range of clinical and environmental microorganisms isolated from 'ordinary' spots such as hospitals and industrial sites ${ }^{6}$ to 'exclusive' locations including the water management systems of 
the International Space Station ${ }^{77}$. With and without known exposure to silver, these microbes carry sil genes or sil gene-related silver resistance systems, many of which are highly conserved and are located in plasmids as transferrable genetic elements ${ }^{6}$. Such resistance determinants can be passed on to other microorganisms by horizontal gene transfer ${ }^{6,78}$, which appears, at least in part, to have facilitated the spread of resistance. Given the numerous human body microbial habitats as the resistance-prone sites, the prospect for microorganism-to-microorganism spread of resistance is high with the applications of NAg. In general, the rate of gene transfer among members of human microflora is 25 -fold higher than those in other environments $^{79}$, potentially giving rise to new resistant populations beyond the original sites, even with an already fading presence of bioavailable silver.

\section{Conclusions and Outlook}

To conclude, the need for targeted surveillance for the development of microbial resistance in NAg commercialisation has been invoked by: (i) the discovery that microorganisms can adapt to the cytotoxic bioavailable silver and becoming resistant to it, (ii) the widespread use of NAg creating opportunities for prolonged exposure of microbial communities to bioavailable silver, and (iii) the potential for spread of resistance determinants, even to other microorganisms without prior exposure to bioavailable silver. Whereby NAg applications are considered effective, such as those in wound dressings and catheters, regular monitoring for resistance development in microbial communities is recommended - on contact sites as well as in other human body microbial habitats with persistent presence of systemically absorbed bioavailable silver. The prospect for resistance development is even more intimidating considering the fact that 'real world' applications of NAg mostly deal with the more resilient microbial communities known as biofilms, including those found colonising wounds and surfaces of catheters ${ }^{80-84}$. The different microbial species in biofilms with their different genotypic and phenotypic traits unite synergistically as a heterogenous and dynamic entity, rendering them less susceptible to antimicrobial agents, including silver $^{85}$. When subjected to ionic or nanocrystalline silver-containing wound treatments, studies have observed less susceptibility of clinically-relevant bacterial biofilms in comparison to their planktonic counterparts $^{86,87}$. Further, these investigations were focused on single species biofilms and therefore may 
not reflect the 'true' toughness of polymicrobial biofilms found in most cases of medical diseases and in nature ${ }^{85}$.

In addition to targeted surveillance for resistance development, the widespread use of NAg needs to be cautiously reassessed for a variety of applications with respect to their risks versus benefits ${ }^{10,88}$. For example, along with the herein realised potential for resistance development, the NAg dietary supplements are marketed based on unverified claims of "immune system boost" and with no clearly defined antimicrobial targets. Also worth highlighting are the complex and yet seemingly inadequate regulations currently placed upon NAg, creating numerous commercialisation loopholes for NAg use. The labelling of NAg supplements as "dietary supplements" for instance, have rendered them essentially immune to the US Food and Drug Administration (FDA)'s strict premarket New Drug Application (NDA) authorisation until after they are already on the market ${ }^{88}$. Similar to that under the European Union's REACH legislation (Registration, Evaluation, Authorization and Restriction of Chemicals) ${ }^{89}$ and Australia's NICNAS (National Industrial Chemicals and Assessment Scheme) ${ }^{90}$, NAg does not meet the criteria as 'new chemical' under the US Environmental Protection Agency (EPA)'s Toxic Substances Control Act (TSCA) with the compositionally identical bulk form silver already on the Chemical Substance Inventory ${ }^{91}$. Such classification has let companies to subject NAg to the same toxicity testing and reporting requirements as bulk silver ${ }^{91}$. This is despite the significant scholarly research reporting differences in their physical and chemical characteristics and consequently, their risks on human and environmental health, as also highlighted in numerous reports by the European Commission's SCENIHR $^{9,91,92}$. The US EPA now acknowledges these differences and assesses NAg separately to bulk silver. As a start, pesticide products that contain NAg must now be registered prior to their release, with the EPA already issuing 'conditional approval' for two products since $2011^{10}$. Numerous NAg products, however, had been launched prior to this change in EPA rules and these products remain in the market, still promoted based on toxicity evaluation for regular silver ${ }^{10}$.

With this Perspective, we seek to raise awareness of the genuine potential for the current widespread use of NAg to lead to development of microbial resistance and we argue the need for a judicial approach 
towards NAg usage. Without effective regulated use of NAg and without efforts to monitor for potential (or realised) resistance development, the capacity of NAg as an alternative antimicrobial weapon in the era of increasing antibiotic resistance will be diminished. The hazard presented by indiscriminate use of NAg is further underscored by intriguing new evidence of shifts in antibiotic resistance gene profiles in microbial communities when subjected to presence of $\mathrm{NAg}^{93}$. Beyond a weakened antimicrobial arsenal, unnecessary applications of NAg will unnecessarily change the balance and dynamics of endogenous microflora, not only those that dwell in the human body but also in the environment. The ripple effect of such disruptions has myriad impacts on human and environmental health and should not be ignored.

\section{Author Information}

Corresponding Author

*E-mail: Cindy.Gunawan@uts.edu.au

\section{Notes}

The authors declare no competing financial interest.

\section{Acknowledgements}

This work was produced with the financial assistance of the University of Technology Sydney under the Chancellor's Research Fellowship Program.

\section{References}

1. Hooper, L. V.; Gordon, J. I. Commensal Host-Bacterial Relationships in the Gut. Science 2001, 292, $1115-1118$.

2. Marambio-Jones, C.; Hoek, E. M. V. A Review of the Antibacterial Effects of Silver Nanomaterials and Potential Implications for Human Health and the Environment. J. Nanopart. Res. 2010, 12, 15311551.

3. Chen, X.; Schluesener, H. J. Nanosilver: A Nanoproduct in Medical Application. Toxicol. Lett. 2008, $176,1-12$. 
4. Yazdankhah, S. P.; Scheie, A. A.; Høiby, E. A.; Lunestad, B. T.; Heir, E.; Fotland, T. Ø.; Naterstad, K.; Kruse, H. Triclosan and Antimicrobial Resistance in Bacteria: An Overview. Microb. Drug Resist. 2006, 12, 83-90.

5. Drury, B.; Scott, J.; Rosi-Marshall, E. J.; Kelly, J. J. Triclosan Exposure Increases Triclosan Resistance and Influences Taxonomic Composition of Benthic Bacterial Communities. Environ. Sci. Technol. 2013, 47, 8923-8930.

6. Mijnendonckx, K.; Leys, N.; Mahillon, J.; Silver, S.; Van Houdt, R. Antimicrobial Silver: Uses, Toxicity and Potential for Resistance. Biometals 2013, 26, 609-621.

7. Senjen, R.; Illuminato, I. http://emergingtech.foe.org.au/wp-content/uploads/2014/06/NanosilverReport-2009.pdf

8. Rai, M.; Yadav, A.; Gade, A. Silver Nanoparticles as a New Generation of Antimicrobials. Biotechnol. $A d v .2009,27,76-83$.

\section{SCENIHR 2014;}

$\underline{\text { http://ec.europa.eu/health/scientific_committees/docs/citizens_silvernanoparticles_en.pdf; }}$ http://ec.europa.eu/health/scientific_committees/emerging/docs/scenihr_o_039.pdf

10. Deardorff, J. 2014; http://articles.chicagotribune.com/2014-02-16/health/ct-nanosilver-met20140216_1_consumer-products-other-antibiotic-drugs-germs

11. The Project on Emerging Nanotechnologies; http://www.nanotechproject.org/cpi/browse/nanomaterials/silver-nanoparticle/

12. Eckhardt, S. Brunetto, P. S.; Gagnon, J.; Priebe, M.; Giese, B.; Fromm, K. M. Nanobio Silver: Its Interactions with Peptides and Bacteria, and Its Uses in Medicine. Chem. Rev. 2013, 113, 4708-4754.

13. Gunawan, C.; Teoh, W. Y.; Marquis, C. P.; Lifia, J.; Amal, R. Reversible Antimicrobial Photoswitching in Nanosilver. Small 2009, 5, 341-344.

14. Sotiriou, G. A.; Pratsinis, S. E. Antibacterial Activity of Nanosilver Ions and Particles. Environ. Sci. Technol. 2010, 44, 5649-5654. 
15. Navarro, E.; Piccapietra, F.; Wagner, B.; Marconi, F.; Kaegi, R.; Odzak, N.; Sigg, L.; Behra, R. Toxicity of Silver Nanoparticles to Chlamydomonas reinhardtii. Environ. Sci. Technol. 2008, 42, 8959-8964.

16. Faunce, T.; Watal, A. Nanosilver and Global Public Health: International Regulatory Issues. Nanomedicine 2010, 5, 617-632.

17. Choi, O.; Hu, Z. Size Dependent and Reactive Oxygen Species Related Nanosilver Toxicity to Nitrifying Bacteria. Environ. Sci. Technol. 2008, 42, 4583-4588.

18. Pal, S.; Tak, Y. K.; Song, J. M. Does the Antibacterial Activity of Silver Nanoparticles Depend on the Shape of the NanoparticleA Study of the Gram-Negative Bacterium Escherichia coli. Appl. Environ. Microbiol. 2007, 73, 1712-1720.

19. Panáček, A. Panáček, A.; Kvítek, L.; Prucek, R.; Kolář, M.; Večeřová, R.; Pizúrová, N.; Sharma, V. K.; Nevěčná, T.; Zbořil, R. Silver Colloid Nanoparticles: Synthesis, Characterization, and Their Antibacterial Activity. J. Phys. Chem. B 2006, 110, 16248-16253.

20. CRC Handbook of Chemistry and Physics $91^{\text {st }}$ ed.; Haynes, W. M., Eds.; CRC Press/Taylor and Francis: Boca Raton, Florida, 2011; pp 8-120.

21. Handbook of Chemistry and Physics $49^{\text {th }}$ ed.; Weast, R. C., Eds.; The Chemical Rubber Co.: Cleveland, Ohio, 1968.

22. http://www.saltlakemetals.com/SolubilityProducts.htm.

23. Jelenko, C. $3^{\text {rd }}$ Silver Nitrate Resistant E. coli: Report of Case. Ann. Surg. 1969, 170, 296-299.

24. McHugh, S. L.; Moellering, R. C.; Hopkins, C. C.; Swartz, M. N. Salmonella typhimurium Resistant to Silver Nitrate, Chloramphenicol, and Ampicillin. Lancet 1975, $i, 235-240$.

25. Gupta, A.; Matsui, K.; Lo, J. -F.; Silver, S. Molecular Basis for Resistance to Silver Cations in Salmonella. Nat. Med. 1999, 5, 183-188.

26. Gupta, A.; Silver, S. Silver as a Biocide: Will Resistance Become a Problem? Nat. Biotechnol. 1998, 16,888 .

27. Gunawan, C.; Teoh, W. Y.; Marquis, C. P.; Amal, R. Induced Adaptation of Bacillus sp. to Antimicrobial Nanosilver. Small 2013, 9, 3554-3560. 
28. Khan, S.; Mukherjee, A.; Chandrasekaran, N. Silver Nanoparticles Tolerant Bacteria from Sewage Environment. J. Environ. Sci. 2011, 23, 346-352.

29. Graves Jr., J. L.; Tajkarimi, M.; Cunningham, Q.; Campbell, A.; Nonga, H.; Harrison, S. H.; Barrick, J. E. Rapid Evolution of Silver Nanoparticle Resistance in Escherichia coli. Front. Genet. 2015, 6, 113.

30. Liu, J.; Wang, Z.; Liu, F. D.; Kane, A. B.; Hurt, R. H. Chemical Transformations of Nanosilver in Biological Environments. ACS Nano 2012, 11, 9887-9899.

31. Wu, Q.; Cao, H.; Luan, Q.; Zhang, J.; Wang, Z.; Warner, J. H.; Watt, A. A. Biomolecule-Assisted Synthesis of Water-Soluble Silver Nanoparticles and Their Biomedical Applications. Inorg. Chem. 2008, $47,5882-5888$.

32. Glover, R. D.; Miller, J. M.; Hutchison, J. E. Generation of Metal Nanoparticles from Silver and Copper Objects: Nanoparticle Dynamics on Surfaces and Potential Sources of Nanoparticles in the Environment. ACS Nano 2011, 5, 8950-8957.

33. Silver, S.; Phung, L. T.; Silver, G. Silver as Biocides in Burn and Wound Dressings and Bacterial Resistance to Silver Compounds. J. Ind. Microbiol. Biotechnol. 2006, 33, 627-634.

34. Walker, M.; Parsons, D. The Biological Fate of Silver Ions Following the Use of Silver-Containing Wound Care Products. Int. Wound. J. 2014, 11, 496-504.

35. Silver, S. Bacterial Silver Resistance: Molecular Biology and Uses and Misuses of Silver Compounds. FEMS Microbiol. Rev. 2003, 27, 341-353.

36. Levard, C.; Mitra, S.; Yang, T.; Jew, A. D.; Badireddy, A. R.; Lowry, G. V.; Brown Jr., G. E. Effect of Chloride on the Dissolution Rate of Silver Nanoparticles and Toxicity to E. coli. Environ. Sci. Technol. 2013, 47, 5738-5745.

37. Gupta, A.; Maynes, M.; Silver, S. Effects of Halides on Plasmid-Mediated Silver Resistance in Escherichia coli. Appl. Environ. Microbiol. 1998, 64, 5042-5045.

38. Grade, S.; Eberhard, J.; Neumeister, A.; Wagener, P.; Winkel, A.; Stiesch, M.; Barcikowski, S. Serum Albumin Reduces the Antibacterial and Cytotoxic Effects of Hydrogel-Embedded Colloidal Silver Nanoparticles. RSC Adv. 2012, 2, 7190-7196. 
39. Klasen, H. J. A Historical Review of the Use of Silver in the Treatment of Burns. II. Renewed Interest for Silver. Burns 2000, 26, 131-138.

40. Percival, S. L.; Bowler, P. G.; Russell, D. Bacterial Resistance to Silver in Wound Care. J. Hosp. Infect. 2005, 60, 1-7.

41. Bowler, P. G.; Duerden, B. I.; Armstrong, D. G. Wound Microbiology and Associated Approaches to Wound Management. Clin. Microbiol. Rev. 2001, 14, 244-269.

42. Duerden, B. I. Virulence Factors in Anaerobes. Clin. Infect. Dis. 1994, 18, S253-S259.

43. Åkesson, A.; Hedströum, S. A.; Ripa, T. Bacillus cereus: A Significant Pathogen in Postoperative and Post-Traumatic Wounds on Orthopaedic Wards. Scand. J. Infect. Dis. 1991, 23, 71-77.

44. Damgaard, P. H.; Granum, P. E.; Bresciani, J.; Torregrossa, M. V.; Eilenberg, J.; Valentino, L. Characterization of Bacillus thuringiensis Isolated from Infections in Burn Wounds. FEMS Immunol. Med. Microbiol. 1997, 18, 47-53.

45. Bendy Jr., R. H.; Nuccio, P. A.; Wolfe, E.; Collins, B.; Tamburro, C.; Glass, W.; Martin, C. M. Relationship of Quantitative Wound Bacterial Counts to Healing of Decubiti: Effect of Topical Gentamicin. Antimicrob. Agents. Chemother. 1964, 10, 147-155.

46. Bridges, K.; Kidson, A.; Lowbury, E. J. L.; Wilkins, M. D. Gentamicin- and Silver-Resistant Pseudomonas in a Burns Unit. Br. Med. J. 1979, 1, 446-449.

47. Starodub, M. E.; Trevors, J. T. Silver Resistance in Escherichia coli R1. J. Med. Microbiol. 1989, 29, 101-110.

48. Kremer, A. N.; Hoffmann, H. Subtractive Hybridization Yields a Silver Resistance Determinant Unique to Nosocomial Pathogens in the Enterobacter cloacae Complex. J. Clin. Microbiol. 2012, 50, 3249-3257.

49. Woods, E. J.; Cochrane, C. A.; Percival, S. L. Prevalence of Silver Resistance Genes in Bacteria Isolated from Human and Horse Wounds. Vet. Microbiol. 2009, 138, 325-329.

50. Saeb, A. T. M.; Al-Rubeaan, K. A.; Abouelhoda, M.; Selvaraju, M.; Tayeb, H. T. Genome Sequencing and Analysis of the First Spontaneous Nanosilver Resistant Bacterium Proteus mirabilis strain SCDR1. bioRxiv 089961; doi: https://doi.org/10.1101/089961 
51. Lansdown, A. B. G. A Pharmacological and Toxicological Profile of Silver as an Antimicrobial Agent in Medical Devices. Adv. Pharmacol. Sci. 2010, article 910686.

52. Shen, X. -C.; Liang, H.; Guo, J. -H.; Song, C.; He, X. -W.; Yuan, Y. -Z. Studies on the Interaction between $\mathrm{Ag}^{+}$and Human Serum Albumin. J. Inorg. Biochem. 2003, 95, 124-130.

53. Klaassen, C. D. Metallothionein IV (Birkhäuser, Basel, 1999).

54. Ballatori, N. Glutathione Mercaptides as Transport Forms of Metals. Adv. Pharmacol. 1994, 27, 271298.

55. Shoeib, T.; Siu, K. W. M.; Hopkinson, A. C. Silver Ion Binding Energies of Amino Acids: Use of Theory to Assess the Validity of Experimental Silver Ion Basicities Obtained from the Kinetic Method. J. Phys. Chem. A 2002, 106, 6121-6128.

56. Jover, J.; Bosque, R.; Sales, J. Quantitative Structure-Property Relationship Estimation of Cation Binding Affinity of the Common Amino Acids. J. Phys. Chem. A 2009, 113, 3703-3708.

57. Lee, V. W. -M.; Li, H.; Lau, T. -C.; Guevremont, R.; Siu, K. W. M. Relative Silver(I) Ion Binding Energies of $\alpha$-Amino Acids: A Determination by Means of the Kinetic Method. J. Am. Soc. Mass Spectrom. 1998, 9, 760-766.

58. Vlachou, E.; Chipp, E.; Shale, E.; Wilson, Y. T.; Papini, R.; Moiemen, N. S. The Safety of Nanocrystalline Silver Dressings on Burns: A Study of Systemic Silver Absorption. Burns 2007, 33, 979-985.

59. Trop, M.; Novak, M.; Rodl, S.; Hellbom, B.; Kroell, W.; Goessler, W. Silver-Coated Dressing Acticoat Caused Raised Liver Enzymes and Argyria-Like Symptoms in Burn Patient. J. Trauma-Injury Infect. Crit. Care 2006, 60, 648-652.

60. Chen, J.; Han, C. M.; Yu, C. H. The Change of the Metabolism of Silver in Silver Nanoparticle Dressing on Burn Wounds. Chin. J. Burns 2004, 20, 161-163.

61. Burk, R. F.; Hill, K. E. Selenoprotein P - Expression, Functions, and Roles in Mammals. Biochim. Biophys. Acta 2009, 1790, 1441-1447.

62. Whiteside, S. A.; Razvi, H.; Dave, S.; Reid, G.; Burton, J. P. The Microbiome of the Urinary Tract - A Role beyond Infection. Nat. Rev. Urol. 2015, 12, 81-90. 
63. Sánchez-Pomales, G.; Mudalige, T. K.; Lim, J. -H.; Linder, S. W. Rapid Determination of Silver in Nanobased Liquid Dietary Supplements Using a Portable X-Ray Fluorescence Analyzer. J. Agric. Food Chem. 2013, 61, 7250-7257.

64. Reed, R. B.; Faust, J. J.; Yang, Y.; Doudrick, K.; Capco, D. G.; Hristovski, K.; Westerhoff, P. Characterization of Nanomaterials in Metal Colloid-Containing Dietary Supplement Drinks and Assessment of Their Potential Interactions after Ingestion. ACS Sustainable Chem. Eng. 2014, 2, 16161624.

65. Quadros, M. E.; Marr, L. C. Silver Nanoparticles and Total Aerosols Emitted by NanotechnologyRelated Consumer Spray Products. Environ. Sci. Technol. 2011, 45, 10713-10719.

66. Bouwmeester, H. et al. 2007;

http://www.researchgate.net/profile/Hans_Bouwmeester/publication/40103450_Health_impact_of_nan otechnologies_in_food_production.pdf (2007).

67. Hinds, W. C. Aerosol Technology, p. 483 (Wiley-Interscience, New York, 1999).

68. Dewhirst, F. E.; Chen, T.; Izard, J.; Paster, B. J.; Tanner, A. C. R.; Yu, W. -H.; Lakshmanan, A.; Wade, W. G. The Human Oral Microbiome. J. Bacteriol. 2010, 192, 5002-5017.

69. Hilty, M.; Burke, C.; Pedro, H.; Cardenas, P.; Bush, A.; Bossley, C.; Davies, J.; Ervine, A.; Poulter, L.; Pachter, L.; Moffatt, M. F.; Cookson, W. O. C. Disordered Microbial Communities in Asthmatic Airways. PLoS One 2010, 5, e8578.

70. Willing, B. P.; Antunes, L. C. M.; Keeney, K. M.; Ferreira, R. B. R.; Finlay, B. B. Harvesting the Biological Potential of the Human Gut Microbiome. BioEssays 2011, 33, 414-418.

71. Bottone, E. J. Bacillus cereus, a Volatile Human Pathogen. Clin. Microbiol. Rev. 2010, 23, 382-398.

72. Blumberg, H.; Carey, T. N. Argyremia: Detection of Unsuspected and Obscure Argyria by the Spectrographic Demonstration of High Blood Silver. J. Am. Med. Assoc. 1934, 103, 1521-1524.

73. White, J. M. L.; Powell, A. M.; Brady, K.; Russell-Jones, R. Severe Generalized Argyria Secondary to Ingestion of Colloidal Silver Protein. Clin. Experim. Dermatol. 2003, 28, 254-256.

74. Rosenman, K. D.; Seixas, N.; Jacobs, I. Potential Nephrotoxic Effects of Exposure to Silver. Br. J. Ind. Med. 1987, 44, 267-272. 
75. Hooker, K. D.; DiPiro, J. T. Effect of Antimicrobial Therapy on Bowel Flora. Clin. Pharm. 1988, 7 , 878-888.

76. Febinia, C.; Ha, C.; Le, C.; Holmes, A. The Role of the Gut Microbiome in Host Systems. Microbiol. Aust. 2015, 36, 14-17.

77. Mijnendonckx, K.; Provoost, A.; Ott, C. M.; Venkateswaran, K.; Mahillon, J.; Leys, N.; Van Houdt, R. Characterization of the survival ability of Cupriavidus metallidurans and Ralstonia pickettii from space-related environments. Microb. Ecol. 2013, 65, 347-360.

78. Ochman, H.; Lawrence, J. G.; Groisman, E. A. Lateral Gene Transfer and the Nature of Bacterial Innovation. Nature 2000, 405, 299-304.

79. Smillie, C. S.; Smith, M. B.; Friedman, J.; Cordero, O. X.; David, L. A.; Alm, E. J. Ecology Drives a Global Network of Gene Exchange Connecting to the Human Microbiome. Nature 2011, 480, 241-244.

80. Lindsay, D.; von Holy, A. Bacterial Biofilms within the Clinical Setting: What Healthcare Professionals Should Know. J. Hosp. Infect. 2006, 64, 313-325.

81. James, G. A.; Swogger, E.; Wolcott, R.; Pulcini, E. D.; Secor, P.; Sestrich, J.; Costerton, J. W.; Stewart, P. S. Biofilms in Chronic Wounds. Wound Repair Regen. 2008, 16, 37-44.

82. Inglis, T. J.; Millar, M. R.; Jones, J. G.; Robinson, D. A. Tracheal Tube Biofilm as a Source of Bacterial Colonization of the Lung. J. Clin. Microbiol. 1989, 27, 2014-2018.

83. Nickel, J. C.; Downey, J. A.; Costerton, J. W. Ultrastructural Study of Microbiologic Colonization of Urinary Catheters. Urology 1989, 34, 284-291.

84. Percival, S. L.; Knapp, J. S.; Edyvean, R. G. J.; Wales, D. S. Biofilm Development on Stainless Steel in Mains Water. Water Res. 1998, 32, 243-253.

85. Rhoads, D. D.; Wolcott, R. D.; Percival, S. L. Biofilms in Wounds: Management Strategies. J. Wound Care 2008, 17, 502-508.

86. Percival, S. L.; Bowler, P.; Dolman, J. Antimicrobial Activity of Silver-Containing Dressings on Wound Microorganisms Using an In Vitro Biofilm Model. Int. Wound J. 2007, 4, 186-191.

87. Bjarnsholt, T.; Kirketerp-Møller, K.; Kristiansen, S.; Phipps, R.; Nielsen, A. K.; Jensen, P. Ø.; Høiby, N.; Givskov, M. Silver against Pseudomonas aeruginosa Biofilms. APMIS 2007, 115, 921-928. 
88. Lipman, A. G. Dietary Supplements: A Call to Action. J. Pain Palliat. Care Pharmacother. 2010, 24, 330-332.

89. REACH 2007; http://ec.europa.eu/environment/chemicals/nanotech/pdf/report_ripon1.pdf

90. NICNAS 2013; https://www.nicnas.gov.au/communications/issues/nanomaterials$\underline{\text { nanotechnology/nicnas-technical-activities-in-nanomaterials/nano-silver-health-hazard-review/silver- }}$ $\underline{\text { nanomaterial-factsheet }}$

91. Faunce, T.; Watal, A. Nanosilver and Global Public Health: International Regulatory Issues. Nanomedicine 2010, 5, 617-632.

92. Hansen, S. F.; Baun, A. When Enough is Enough. Nat. Nanotechnol. 2012, 7, 409-411.

93. Ma, Y.; Metch, J. W.; Yang, Y.; Pruden, A.; Zhang, T. Shift in Antibiotic Resistance Gene Profiles Associated with Nanosilver During Wastewater Treatment. FEMS Microbiol. Ecol. 2016, 92, fiw022. 


\section{Box 1 Bioavailable silver from nanosilver-containing products}

Incorporation of nanosilver (NAg) in medical and consumer products is via surface coating or impregnation of particulates in fibres, foams, latex, hydrogels, hydrocolloids (e.g. wound dressings and catheters) just to name a few, or via suspending of particulates in creams and solutions (e.g. topical creams and dietary supplements) (Figure 1). When in use, the intended contact of NAg with aqueous environments, such as body fluids (wound fluid, gastrointestinal fluid, bloodstream, urine), will lead to the release and potentially, subsequent absorption, distribution and accumulation of cytotoxic silver species in microorganism-inhabited organs and tissues. Upon contact with body fluids, the released silver particulates will aggregate or agglomerate to

form clusters, while the leached silver ions will interact with the presence of biomolecules (amino acids, peptides, proteins) and anions (halide $(\mathrm{Cl}, \mathrm{Br}, \mathrm{l})$, phosphate), to form silver precipitates and complexes. Excluding the biologically inert precipitates $\left(\mathrm{AgCl}-\mathrm{K}_{\mathrm{sp}}=1.77 \mathrm{x}\right.$ $10^{-10} \mathrm{M}_{,}{ }^{20} \mathrm{AgBr}-\mathrm{K}_{\mathrm{sp}}=7.7 \times 10^{-13} \mathrm{M}^{21} \mathrm{Agl}-\mathrm{K}_{\mathrm{sp}}=1.5 \times 10^{-16} \mathrm{M}^{21} \mathrm{Ag}_{3} \mathrm{PO}_{4}-\mathrm{K}_{\mathrm{sp}}=8.89 \times 10^{-17} \mathrm{M}^{22}$ organo Ag precipitates), these transformed silver species are increasingly realised to exhibit cytotoxic effects on microbes. If persisted in microbial habitats, the known bioavailability of Ag clusters, the leached silver ions as well as their 'derivatives', including the organo Ag complexes (Ag-amino acid, Agpeptide, Ag-protein complexes) and soluble $\mathrm{Ag}(\mathrm{l})$-halide anionic complexes ( $\mathrm{AgX}_{\mathrm{n}}{ }^{(1-n)}$ ) infer a potential response of microbial adaptation. Note that higher levels of halide anions in body fluids, such as $\mathrm{Cl}$ in wounds, will bring $\mathrm{Ag}$ halide precipitate 'back' into solution as anionic complexes.

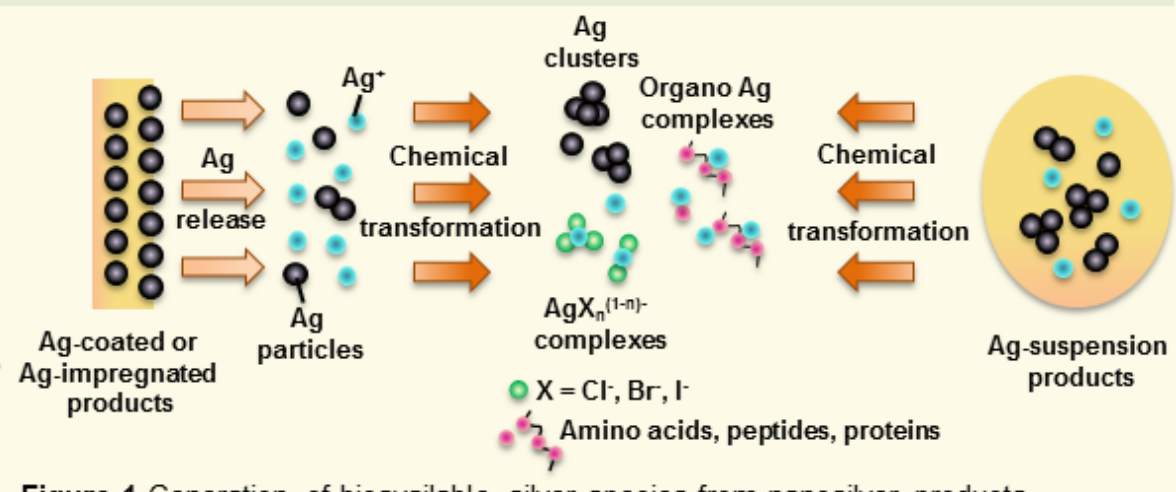

Figure 1 Generation of bioavailable silver species from nanosilver products. 


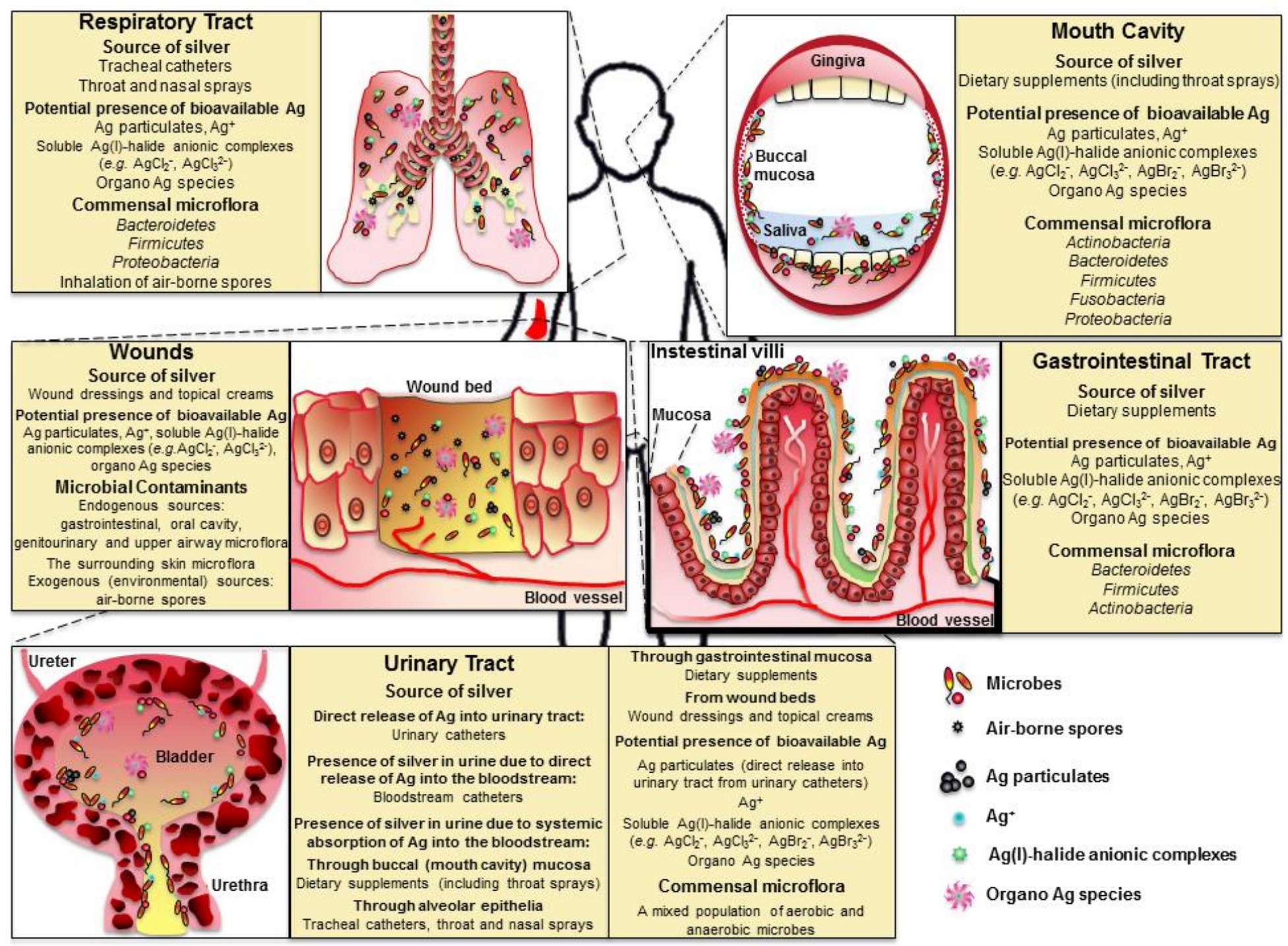

Figure 2. Resistance-prone sites: potential prolonged exposure of resident commensal microflora to the presence of bioavailable silver in various human body locations. Presence of bioavailable silver is through release, absorption, distribution and accumulation of silver species from nanosilver products. 